\title{
MANTOJUMA LİGUMA SEKAS UN TO JURIDISKĀ DABA
}

\section{CONSEQUENCES OF AN INHERITANCE CONTRACT AND ITS LEGAL NATURE}

\author{
Alise Reide, Mg. iur. \\ Latvijas Universitātes Juridiskās fakultātes doktorante, \\ Civiltiesisko zinātņu katedras lektore
}

\begin{abstract}
Summary
According to Article 639 of the Civil Law, with an inheritance contract one party (an estate-leaver) grants the rights to his future inheritance or its part to another party (a contractual heir). As the inheritance contract establishes only a future invitation to inherit, it grants to the contractual heir only the right to wait for his future inheritance, but not an immediately effective right to the present property of the estate-leaver. However, the right of the estate-leaver to dispose of the movable and immovable property bequeathed by the inheritance contract can be restricted. If the inheritance contract concerns immovable property and it has not been registered in the Land Register, it is not valid against third persons, and the estate-leaver can fully exercise his property rights.
\end{abstract}

Atslēgvārdi: mantojuma līgums, mantojuma līguma sekas, līgumiskā mantošana, līgumiskais mantinieks.

Keywords: inheritance contract, consequences of an inheritance contract, contractual inheritance, contractual heir.

Mantojuma līgums ir viens no trim iespējamajiem aicinājuma mantot pamatiem lïdztekus testamentam un likumam. Turklāt saskaņā ar Civillikuma (turpmāk - CL) 389. panta trešo daļu līgumiskai mantošanai ir prioritāte iepretim testamentārajai un likumiskajai mantošanai. Tiek lēsts, ka $78 \%$ Latvijas iedzīvotāju, kuri vērsušies pie zvērināta notāra pēc konsultācijas par juridiskajām iespējām sakārtot savas dzīves laikā uzkrātās mantas, tiesību un saistîbu nākotni, nemaz nezina, ka savu pēdējo gribu var paust arī mantojuma līgumā. ${ }^{1}$ Tādēl šì raksta mērkisis ir popularizēt mantojuma līgumu kā vienu no pēdējās gribas rīkojumiem, akcentējot, pēc autores domām, būtiskākās mantojuma līguma tiesiskās sekas un analizējot to juridisko dabu. ${ }^{2}$ Atbilstoši mantojuma līguma

${ }^{1}$ Sk. Latvijas Zvērinātu notāru padome. Trīs svarīgākie dokumenti, kuriem jābūt katra cilvēka personīgajā arhīvā. Pieejams: https://www.latvijasnotars.lv/articles/tris-svarigakie-dokumenti-kuriem-jabutkatra-cilveka-personigaja-arhiva [aplūkots 10.01.2021.].

2 Aplūkojot mantojuma līguma institūta vēsturisko attīstību Latvijas teritorijā, norādāms, ka arī gandrīz pirms gadsimta mantojuma līgums praksē netika bieži lietots. Sk. Bukovskis V. Latvijas mantojumu tiesibu projekts. Tieslietu Ministrijas Vēstnesis, 1929, Nr. 11/12, 376. lpp. 
legāldefinīcijai, kas ietverta CL 639. panta pirmajā daḷā, ar mantojuma līgumu viens lìdzējs otram vai vairāki lìdzēji cits citam piešksir tiesību uz savu nākamo mantojumu vai tā daḷu, nodibinot līgumisko mantošanu. ${ }^{3}$ Tātad mantojuma līguma juridiskā daba ir mantinieka iecelšana un mantojuma līguma priekšmets ir nākamais mantojums kā kopība saskaṇā ar CL 382. pantu vai tā daḷa. ${ }^{4}$ Tas, ka mantinieka iecelšana, atšķirībā no citiem pēdējās gribas rīkojumiem, ir viena no mantojuma līguma nozīmīgākajām pazīmēm, tika pausts arī CL priekštecī jeb Baltijas vietējo likumu kopojumā (turpmāk - BVLK), kura 2481. pantā mantojuma līgums tika dēvēts arī par mantinieka iecelšanas līgumu. ${ }^{5}$

Tiesību doktrīnā mantojuma lìgums ir atzìts par visstabilāko mantošanas pamatu, skaidrojot to ar divpusējā tiesiskā darījuma (divpusējā līguma) ${ }^{6}$ abpusēji saistošo raksturu, kas paredz saistības abām līguma pusēm un piešķir tām korespondējošas tiesības, un likumā noteikto aizliegumu atsaukt mantojuma līgumu vienpusējā kārtībā. ${ }^{7}$ Mantojuma līgums ir divpusēja saistība, kurā viens līdzējs - mantojuma atstājējs - piešķir mantojuma tiesību, savukārt otrs lìdzējs ligumiskais mantinieks - apṇemas mantojumu pieņemt. Jānorāda, ka, pamatojoties uz CL 651. panta otro daḷu, kā arī CL 689. panta otro teikumu, līgumiskais mantinieks var mantojumu atraidìt vienīgi tad, ja viņam šāda tiesība mantojuma līgumā ir ìpaši piešķirta. ${ }^{8}$ Attiecīgi, ja līgumiskais mantinieks lìgumā nav pielīdzis sev tiesību mantojumu atraidīt, tad viņam mantojums ir obligāti jāpieņem, kas ir priekšnosacījums mantojuma iegūšanai. ${ }^{9} \mathrm{Li} d z$ ar to pamatots ir profesora Vasilija Sinaiska secinātais, ka “Tādā kārtā pēc CL iznāk, ka mantojuma līguma juridiskā dabā ietilpst ne tikai aicinājums mantot, bet arī mantojuma pieņemšana [..."10. Arī jaunākajos mantojuma tiesību pētījumos tiek norādīts uz mantojuma pieņemšanas prezumpciju līgumiskajā mantošanā, ja līgumiskajam mantiniekam mantojuma līgumā nav paredzētas tiesības mantojumu atraidīt. Mantojuma pieņemšanas prezumpcija ir uzskatāma kā izṇēmums no vispārīgā principa. Atbilstoši tam ir nepieciešams mantinieka gribas izteikums mantojumu pieņemt, nevis atraidìt. ${ }^{11}$ Šìs ir vienas no nozīmīgākajām mantojuma līguma sekām, kas atš̌kir līgumisko mantošanu no testamentārās un likumiskās mantošanas.

\footnotetext{
${ }^{3}$ Civillikums: LV likums. Pieņemts 28.01.1937. [aplūkots 10.01.2021.].

${ }^{4}$ Augstākās tiesas Senāta 25.03.2009. spriedums lietā Nr. SKC-113/2009. Pieejams: http://at.gov.lv/lv/tiesuprakse/judikaturas-nolemumu-arhivs/civillietu-departaments/klasifikators-pec-lietu-kategorijam/civillikums/otra-dala-mantojuma-tiesibas-382-840pants/ceturta-nodala-ligumiska-mantosana-639-654-pants [aplūkots 15.01.2021.].

${ }^{5}$ Vietējo civillikumu kopojums. Vietējo likumu kopojuma III. dal̦a. Rīga: Valters un Rapa, 1928, 2481. pants, 279. lpp.

${ }^{6}$ Balodis K. Ievads Civiltiesībās. Rīga: Zvaigzne ABC, 2007, 171., 181.-183. lpp.

7 Čakste K. Civiltiesības. Rīga: Zvaigzne ABC, 2011, 35. lpp.; Krauze R., Gencs Z. Latvijas Republikas Civillikuma komentāri. Mantojuma tiesỉbas (382.-840. p.). Rīga: Mans Īpašums, 1997, 183. lpp.

${ }^{8}$ Rỉgas apgabaltiesas 07.08.2018. spriedums lietā Nr. C30656716. Pieejams: https://manas.tiesas.lv/ eTiesasMvc/nolemumi/pdf/389955.pdf [aplūkots 12.01.2021.].

9 Senāta 25.02.2019. spriedums lietā Nr. SKC-117/2019. Pieejams: http://at.gov.lv/lv/tiesu-prakse/judikaturas-nolemumu-arhivs/civillietu-departaments/hronologiska-seciba?year=2019 [aplūkots 28.01.2021.].

10 Sinaiskis V. Sukcesija un mantojuma līgums. Jurists, 1939, Nr. 1/2, 3.-8. lpp.

${ }^{11}$ Latvijas Zvērinātu notāru padome. Civillikuma Mantojuma tiesību daḷas tiesiskā regulējuma problēmjautājumi un to modernizācijas nepieciešamība. Rīga, 2017, 116. lpp. Pieejams: https://www.tm.gov.lv/lv/ nozares-politika/petijumi [aplūkots 25.02.2021.].
} 
Neskatoties uz mantojuma liguma saistību tiesisko raksturu, mantojuma līgums ir nošķirams no citām saistībām, ${ }^{12}$ jo saskaṇā ar CL 640. pantu ar mantojuma līgumu tiek nodibināta ne tikai personiska saistība, bet pati mantojuma tiesība, kas tiks realizēta tikai pēc tam, kad mantojums būs atklājies atbilstoši CL 389. panta pirmās daļas un CL 655. panta noteikumiem. CL 646. pants nosaka: "Mantojuma līgums nodibina tikai nākamo aicinājumu mantot un tādēḷ, kamēr mantojuma atstājējs vēl ir dzīvs, piešḳir līgumiskam mantiniekam vienīgi nogaidu tiesību uz viṇa nākamo mantojumu, bet nevis tūliṇ, spēkā esošu tiesību uz mantojuma atstājēja tagadējo mantu." Ievērojot to, ka ar mantojuma līgumu līgumiskajam mantiniekam tiek piešķirta tikai nogaidu tiesība uz nākamo mantojumu, ir jāpiekrīt juridiskajā literatūrā norādītajam, ka šis nākamā mantojuma lielums visā pilnībā nodibināsies tikai ar mantojuma atklāšanos. ${ }^{13} \mathrm{Li} d z$ ar to îpaša mantojuma līguma raksturojošā pazīme ir tā konsensuālā daba attiecībā uz mantojuma tiesību, jo mantojuma līguma būtība neparedz reālu līguma izpildi tā noslēgšanas brīdī par pašu mantojuma tiesību. ${ }^{14}$

Tomēr vienlaikus mantojuma līgumā līgumiskajam mantiniekam var tikt noteiktas papildu saistības un pienākumi pret mantojuma atstājēju, kas ir pildāmi līdz ar mantojuma līguma noslēgšanu. Tiesību zinātnieki par saistībām un pienākumiem, kas līgumiskajam mantiniekam jāveic mantojuma atstājēja dzīves laikā, ir skaidrojuši, ka uz tiem nav attiecināma mantojuma līguma nogaidu tiesība uz pašu mantojumu. ${ }^{15}$ Pētot tiesu praksi, secināms, ka šādas papildu saistības un pienākumi var būt visdažādākie. Piemēram, līgumiskā mantinieka pienākums nodrošināt mantojuma atstājēju ar mūža uzturu, ik mēnesi izmaksājot konkrētu naudas summu mantojuma atstājējam. ${ }^{16}$ Tāpat pienākums mantojuma atstājēja dzīves laikā apgādāt viṇu ar pārtikas produktiem, pienākums aprūpēt mantojuma atstājēju vecuma nespēka un slimības gadījumā, ieskaitot ārsta izsaukšanu, ārstniecības izdevumu apmaksu, medikamentu iegādi, veḷas mazgāšanu, dzīvojamo telpu apkures nodrošināšanu atbilstošā temperatūrā un mājokḷa elektroenergijijas rēḳinu segšanu no līgumiskā mantinieka līdzekḷiem. ${ }^{17}$ Turklāt nereti mantojuma līgumos tiek ietverti arī dažādi pienākumi, kas veicami pēc mantojuma atstājēja nāves. Piemēram, īpaši nosacījumi mantojuma atstājēja apbedīšanai un kapa vietas kopšanai. ${ }^{18}$ Tomēr ir jānorāda, ka šādi līgumiskā mantinieka papildu pienākumi un saistības ir līgumslēdzēju privātautonomijas izpausme. ${ }^{19}$ Saskaṇā ar tiesu praksē atzìto nedz CL 639. pants, nedz arī CL 640. pants "neprasa, lai ar

12 Torgāns K. Saistību tiesības. 2. papild. izd. Rīga: Tiesu namu aǵentūra, 2018, 17.-19. lpp.

13 Sinaiskis V. 1939, 3.-8. lpp.

14 Kalniņš E. Tiesisks darījums. Grām.: Privāttiesību teorija un prakse. Raksti privāttiesībās. Rīga: Tiesu namu aǵentūra, 2005, 140. lpp.; Krauze R., Gencs Z. 1997, 188. lpp.

15 Krauze R., Gencs Z. 1997, 188. lpp.

16 Augstākās tiesas 20.09.2016. spriedums lietā Nr. SKC-121/2016 (C17090511). Pieejams: https://manas. tiesas.lv/eTiesasMvc/nolemumi/pdf/281404.pdf [aplūkots 15.01.2021.].

17 Vidzemes apgabaltiesas 30.04.2019. spriedums lietā Nr. C14034716. Pieejams: https://manas.tiesas.lv/ eTiesasMvc/nolemumi/pdf/384446.pdf [aplūkots 19.01.2021.].

18 Alūksnes rajona tiesas 16.09.2015. spriedums lietā Nr. C08054214. Pieejams: https://manas.tiesas.lv/eTiesasMvc/nolemumi/pdf/233901.pdf; Rīgas pilsētas Vidzemes priekšpilsētas tiesas 09.03.2015. spriedums lietā Nr. C30729012. Pieejams: https://www.tiesas.lv/nolemumi/pdf/217155.pdf; Vidzemes apgabaltiesas 30.04.2019. spriedums lietā Nr. C14034716. Pieejams: https://manas.tiesas.lv/eTiesasMvc/nolemumi/ pdf/384446.pdf [aplūkoti 23.01.2021.].

19 Sinaiskis V. Mantojuma tiesības. Tieslietu Ministrijas Vēstnesis, 1940, Nr. 1, 32.-33. lpp. 
mantojuma līgumu ieceltais mantinieks veiktu kādas darbības vai dotu apsolijumu kā pateicîbu mantojuma atstājējam" 20 .

Tiesiskās sekas attiecībā uz līgumiskā mantinieka papildu pienākumu un saistību nepildī̌sanu var iedalīt atbilstoši šo pienākumu izpildes laikam - pirms vai pēc mantojuma atklāšanās. Ja līgumiskais mantinieks mantojuma līgumā ir uzņēmies papildu pienākumus, kas jāpilda mantojuma atstājēja dzìves laikā, tad mantojuma atstājējs ir tiesīgs prasìt attiecīgo pienākumu izpildi tiesas ceḷā. Tiesību doktrīnā tiek norādìts, ka minētais prasījums varētu būt pamatots ar CL 1587. pantu. ${ }^{21}$ Savukārt, ja līgumiskajam mantiniekam uzṇemtie pienākumi ir jāpilda pēc mantojuma atstājēja nāves, tad iespējama mantojuma atraušana lìgumiskajam mantiniekam viṇa necienības dēl, pamatojoties uz CL 824. pantu. Piemēram, ja līgumiskais mantinieks nepilda savu pienākumu apbedìt mantojuma atstājēju, tad saskaņā ar CL 824. panta 6. punktu līgumisko mantinieku var atzìt par necienīgu mantinieku un atraut vinam mantojumu. ${ }^{22}$ Tiek uzskatìts, ka tādējādi mantinieks izrāda necieṇu pret mantojuma atstājēju un viṇa pausto pēdējo gribu. ${ }^{23}$

Jau romiešu tiesībās tika atzīta iespēja liegt saṇemt mantojumu mantinieka necienības dēl, kā arī iespēja atṇemt mantojumu arī tādam mantiniekam, kurš jau bija mantojumu pieṇēmis, bet izrādījies necienīgs mantot (heres indignus). ${ }^{24}$ Arī mūsdienās mantojuma atraušana ir iespējama gadījumā, ja necienīgais mantinieks mantojumu jau ir ieguvis. Mantinieks, kuram mantojums tiek atrauts viṇa necienỉbas dēl, ir uzskatāms par atkritušu atbilstoši CL 406. panta noteikumiem. Lai gan tiesību pētniekiem nav bijusi vienprātība par to, vai mantojuma atraušana var tikt īstenota un vai atraušanas tiesiskās sekas ir saistošas visos trijos aicinājuma mantot pamatos, autore uzskata, ka atraut mantojumu var neatkarīgi no mantošanas pamata, t. i., gan likumiskajā, gan testamentārajā, gan arī līgumiskajā mantošanā. ${ }^{25}$ Respektīvi, ja līgumiskais mantinieks tiek atzìts par necienīgu mantinieku, pamatojoties uz CL 824. panta 6. punktu, bet vienlaikus šis līgumiskais mantinieks ir arī tuvākais likumiskais mantinieks, tad atraušanas tiesiskās sekas attiecībā uz šo mantinieku ir saistošas arī likumiskajā mantošanā. Prasību par mantojuma atraušanu var celt persona, kurai mantojums pārietu pēc tā atraušanas (piemēram, substitūts, ja līgumiskajam mantiniekam tāds bija iecelts; līdzmantinieks, ja mantojums novēlēts vairākiem līgumiskajiem mantiniekiem; testamentārais mantinieks vai tuvākais likumiskais mantinieks), kā arī prokurors likumā paredzētajos gadījumos. $^{26}$

${ }^{20}$ Rīgas pilsētas Vidzemes priekšpilsētas tiesas 13.02.2018. spriedums lietā Nr. C30546617. Pieejams: https:// www.tiesas.lv/nolemumi/pdf/386700.pdf [aplükots 27.01.2021.].

${ }^{21}$ Krauze R., Gencs Z. 1997, 191. lpp.

${ }^{22}$ Vidzemes rajona tiesas 28.06.2018. spriedums lietā Nr. C14034716. Pieejams: https://manas.tiesas.lv/ eTiesasMvc/nolemumi/pdf/384528.pdf; Vidzemes apgabaltiesas 15.05.2007. spriedums lietā Nr. CA0028-07. Tiesu prakses vispārinājums strīdos par mantojuma tiesỉbām. Pieejams: http://www.at.gov.lv/lv/ judikatura/tiesu-prakses-apkopojumi/civiltiesibas [aplūkoti 25.02.2021.].

${ }^{23}$ Gencs Z. Civillikuma komentāri. Otrā daļa. Mantojuma tiesības (655.-840. pants). Rīga: Tiesu namu ağentūra, 2012, 365. lpp.

${ }^{24}$ Kalniņš V. Romiešu civiltiesību pamati. 2. izd. Rīga: Zvaigzne ABC, 2010, 193. lpp.

25 Erdmann C. System des Privatrechts der Ostseeprovinzen Liv-, Est- und Curland. Dritter Band. Erbrecht. Riga: N. Kymmel's Verlag, 1892, S. 503; Буковский В. Свод Гражданских Узаконений Губерний Прибалтийских сь продолжением 1912-1914 г. г. и с разъяснениями вь 2 томах. Томь I. Рига: Г. Гемпель и Ко., 1914, с. 1081-1082; Gencs Z. Mantojumu kārtošana. Rīga: Mans Īpašums, 1996, 323. lpp.

${ }^{26}$ Sk. CL 826., 827. pantu. 
CL 646. pantā ietvertā mantojuma līguma nogaidu tiesība uz mantojumu izpaužas tādējādi, ka mantojuma atstājējs arī pēc mantojuma līguma noslēgšanas saglabā īpašuma tiesības uz savu mantu, kas novēlēta līgumiskajam mantiniekam. Tiesu praksē ir norādīts, ka "Atbilstoši Civillikuma 646. panta nosacijjumiem ar mantojuma līgumu [līgumiskajam mantiniekam] netiek nodibinātas īpašuma tiesības uz dzīvā mantojuma atstājēja īpašumu, bet gan piešķirta nogaidu tiesība uz nākamo mantojumu. Tādejādi atzīstams, ka mantojuma līguma noslēgšana par tiesību piešķiršanu uz nekustamo īpašumu, kā nākamo mantojumu, nav uzskatāma par īpašuma apgrūtināšanu ar lietu tiesībām, bet gan par līgumisko mantojuma tiesību nodibināšanu Civillikuma 639. panta izpratnē"27. Tomēr mantojuma atstājēja īpašuma tiesības var tikt ierobežotas attiecīgā apmērā atbilstoši mantojuma līguma vai likuma noteikumiem. Proti, pamatojoties uz CL noteikumiem, mantojuma atstājēja valdījuma un lietojuma tiesības attiecībā uz mantu, kas novēlēta līgumiskajam mantiniekam, nav ierobežotas, bet tiesības rīkoties ar šo mantu gan var tikt ierobežotas. Ierobežojumus rīkoties mantojuma atstājējam ar savu mantu iespējams noteikt kā kustamai, tā arī nekustamai mantai.

Saskaṇā ar CL 648. panta pirmo daḷu mantojuma atstājējs ir tiesīgs savas dzīves laikā brīvi rīkoties ar savu kustamo mantu un pat mērenos apmēros to dāvināt, protams, ja vien mantojuma atstājējs mantojuma līgumā nav atteicies no šādām tiesībām. No minētās tiesību normas secināms, ka bezatlīdzības atsavinājumu likums piel̦auj izdarīt "mērenos apmēros", kas tiesību doktrīnā tiek skaidrots kā tāds apmērs, kas būtiski nesamazina ar mantojuma līgumu novēēētās mantas apmērus. Tiek norādīts, ka arī, atsavinot mantu pret atlīdzību, mantojuma atstājējam ir jāraugās, lai ar šādu rīcību netiktu būtiski samazināta vai pat likvidēta mantojuma līgumā novēlētā manta nolūkā atņemt līgumiskajam mantiniekam viņa mantojuma tiesību. ${ }^{28} \mathrm{CL}$ 648. panta otrā daḷa paredz tiesiskās sekas gadījumam, ja mantojuma atstājējs mantu atsavina ar acīmredzamu nolūku atṇemt mantojuma līgumā ieceltajam mantiniekam ar šo līgumu piešķirto mantojuma tiesību. Tādā situācijā likums paredz iespēju līgumiskajam mantiniekam attiecīgo atsavinājumu apstrīdēt, mantojuma atstājējam vēl dzīvam esot. Turklāt, ja mantojuma atstājējs samazina savu mantu tādā apmērā, kādā šāda rīcība varētu tikt uzskatīta par izlaidīgu vai izšḳērdīgu dzīvesveidu, līgumiskais mantinieks var prasìt, lai mantojuma atstājējam tiek nodibināta aizgādnība. ${ }^{29}$ Lai gan CL 648. panta otrā daḷa neizdala konkrētu mantas veidu, tomēr tajā norādītās tiesiskās sekas noteiktos apstākḷos varētu tikt attiecinātas ne tikai uz kustamu mantu, bet arī uz nekustamo îpašumu. ${ }^{30}$

CL 649. pants nosaka: "Ja mantojuma liguma priekšmets ir nekustams ippašums un šo līgumu ieved zemes grāmatās mantojuma atstājējam dzīvam esot, tad viņš šo nekustamo īpašumu var atsavināt, ieḳilāt vai apgrūtināt ar lietu tiesībām tikai ar līgumiskā mantinieka piekrišanu.” Attiecīgā tiesību norma ir skatāma kopsakarā arī ar CL 643. pantu, kas paredz: ja mantojuma līgums attiecas uz nekustamu īpašumu, tad tas ir jāieraksta zemes grāmatās, lai tas būtu

\footnotetext{
${ }^{27}$ Rīgas pilsētas Vidzemes priekšpilsētas tiesas 13.02.2018. spriedums lietā Nr. C30546617. Pieejams: https://www.tiesas.lv/nolemumi/pdf/386700.pdf [aplūkots 27.01.2021.].

${ }^{28}$ Krauze R., Gencs Z. 1997, 189. lpp.

29 Sk. Civilprocesa likuma 34. nodal̦u. Civilprocesa likums: LV likums. Pieņemts 14.10.1998. [11.03.2021.].

30 Vidzemes apgabaltiesas 14.10.2020. spriedums lietā Nr. C21034416. Pieejams: https://manas.tiesas.lv/ eTiesasMvc/nolemumi/pdf/440505.pdf [aplūkots 15.03.2021.].
} 
spēkā pret trešajām personām. Judikatūrā ir atzìts, ka CL 643. pantā ietvertais noteikums par līguma ierakstǐšanu zemesgrāmatā nav īpašumtiesību nostiprinājuma ieraksts, bet gan nodrošinājuma ieraksts, kas liedz mantojuma atstājējam atsavināt nekustamo ìpašumu. Tiek skaidrots, ka "CL 643. pants līguma ierakstī̌sanu zemesgrāmatā saista ar līguma spēku attiecībā uz trešajām personām, apstiprinot ar to mantojuma lìguma spēku attiecībā pret līgumslēdzējām pusēm neatkarīgi no ieraksta zemesgrāmatā"31.

Lìdz ar to secināms, ka iepriekš aplūkotajās tiesību normās ir iekḷauta tiesība, bet ne pienākums mantojuma līgumu attiecībā uz nekustamu ìpašumu registrēt zemesgrāmatās. Tādēl, ja mantojuma līgums nav ticis reǵistrēts zemesgrāmatās, mantojuma atstājējs ir tiesīgs savas dzīves laikā rīkoties ar nekustamo īpašumu bez līgumiskā mantinieka piekrišanas. Minēto apstiprina arī tiesu prakse, norādot, ka "No Civillikuma 649. panta izriet, ja puses vēlas nodrošināt mantojuma līguma izpildi attiecībā uz nekustamu īpašumu, tās var vienoties par mantojuma līguma ierakstī̌sanu kā apgrūtinājumu zemesgrāmatā, bet likums nenosaka obligātu nosacỉjumu mantojuma līguma ievešanai zemesgrāmatā līdz ar līguma noslēgšanu"32. Turklāt, ja mantojuma līgums attiecībā uz nekustamo īpašumu nebūs reǵistrēts zemesgrāmatās, šāds mantojuma līgums nebūs spēkā iepretim trešajām personām un neradīs juridiskas sekas trešajām personām, kurām mantojuma atstājējs kā ipašnieks konkrēto nekustamo ìpašumu atsavinājis, ieḳīājis vai apgrūtinājis ar lietu tiesībām bez līgumiskā mantinieka piekrišanas. ${ }^{33}$

Lai gan mantojuma līguma neierakstīšana zemesgrāmatās neietekmē līguma spēkā esamību attiecībā pret tā līdzējiem, aplūkojot tiesu praksi, ir secināms, ka šādam zemesgrāmatās nereǵistrētam mantojuma līgumam, atklājoties mantojumam, var būt tālejošas sekas pie mantojuma pieņemšanas. Proti, ja mantojuma līgumā līgumiskajam mantiniekam ir piešķirta tiesība mantojumu atraidìt, bet mantojuma līgums nebūs reǵistrēts zemesgrāmatās, tad šādā gadījumā nevarētu tikt piemērota līgumiskās mantošanas mantojuma pieņemšanas prezumpcija un līgumiskais mantinieks varētu tikt uzskatīts par nezināmu mantinieku, kuram jo ipaši svarīgi būtu ievērot uzaicinājuma termiṇu, lai varētu realizēt savu mantojuma tiesību. ${ }^{34}$

\section{Kopsavilkums}

1. Ar mantojuma līgumu, kura priekšmets ir nākamais mantojums kā kopība saskaņā ar CL 382. pantu vai tā daḷa, tiek iecelts mantinieks un nodibināta mantojuma tiesība, kas varēs tikt realizēta, tikai mantojumam atklājoties. Tādēl ìpaša mantojuma līguma raksturojošā pazìme ir tā konsensuālā daba attiecībā uz mantojuma tiesību, jo mantojuma līguma būtība neparedz reālu lìguma izpildi tā noslēgšanas brīdī par pašu mantojuma tiesību.

31 Senāta 22.05.1996. spriedums lietā Nr. SPC-50. Latvijas Republikas Augstākās tiesas Senāta spriedumi un lēmumi. Rīga: Latvijas Tiesnešu mācību centrs, 1996, 162.-163. lpp.

32 Augstākās tiesas 18.04.2016. lēmums lietā Nr. SKC-1659/2016. Pieejams: https://manas.tiesas.lv/eTiesasMvc/nolemumi/pdf/367514.pdf [aplūkots 05.02.2021.].

${ }^{33}$ Vidzemes apgabaltiesas 14.10.2020. spriedums lietā Nr. C21034416. Pieejams: https://manas.tiesas.lv/ eTiesasMvc/nolemumi/pdf/440505.pdf [aplūkots 15.03.2021.].

34 Rīgas apgabaltiesas 07.08.2018. spriedums lietā Nr. C30656716. Pieejams: https://manas.tiesas.lv/eTiesasMvc/nolemumi/pdf/389955.pdf [aplūkots 12.01.2021.]. 
2. Mantojuma līgumā ieceltajam mantiniekam var tikt noteiktas papildu saistības un pienākumi pret mantojuma atstājēju, kuri ir pildāmi līdz ar mantojuma līguma noslēgšanu, un uz tiem nav attiecināma mantojuma līguma nogaidu tiesība uz mantojumu. Tiesiskās sekas attiecībā uz šādu pienākumu nepildī̌sanu varētu iedalìt atbilstoši pienākumu izpildes laikam - pirms vai pēc mantojuma atklāšanās. Ja pienākumi ir jāpilda mantojuma atstājēja dzīves laikā, mantojuma atstājējs ir tiesīgs prasīt attiecīgo pienākumu izpildi tiesas ceḷā, savukārt, ja pienākumi pildāmi pēc mantojuma atstājēja nāves, tad iespējama mantojuma atraušana līgumiskajam mantiniekam viṇa necienības dēl, turklāt mantojuma atraušanas tiesiskās sekas ir saistošas visos trijos aicinājuma mantot pamatos.

3. Lai gan CL 646. pantā ietvertā mantojuma līguma nogaidu tiesība uz mantojumu izpaužas kā mantojuma atstājēja īpašuma tiesību saglabāšana uz mantu, kas novēlēta līgumiskajam mantiniekam, arī pēc mantojuma līguma noslēgšanas, tomēr mantojuma atstājēja īpašuma tiesības var tikt ierobežotas attiecīgā apmērā atbilstoši mantojuma līguma vai likuma noteikumiem. Pamatojoties uz CL noteikumiem, mantojuma atstājējam var tikt ierobežotas tiesības rīkoties ar savu kustamo un arī nekustamo mantu.

4. CL 643. un 646. pantā ir iekḷauta tiesība, bet ne pienākums mantojuma līgumu attiecībā uz nekustamu ìpašumu reǵistrēt zemesgrāmatās. Ja mantojuma līgums nav ticis reǵistrēts zemesgrāmatās, mantojuma atstājējs ir tiesīgs savas dzīves laikā rīkoties ar nekustamo īpašumu bez līgumiskā mantinieka piekrišanas, turklāt šāds mantojuma līgums nebūs spēkā iepretim trešajām personām un neradīs juridiskas sekas trešajām personām, kurām mantojuma atstājējs kā īpašnieks konkrēto nekustamo ìpašumu atsavinājis, ieḳîāajis vai apgrūtinājis ar lietu tiesībām bez līgumiskā mantinieka piekrišanas.

5. Mantojuma līguma neierakstǐšana zemesgrāmatās neietekmē līguma spēkā esamību attiecībā pret tā līdzējiem, tomēr zemesgrāmatās nereǵistrētam mantojuma līgumam, atklājoties mantojumam, var būt tālejošas sekas pie mantojuma pieņemšanas. Ja mantojuma līgumā mantiniekam ir piešķirta tiesība mantojumu atraidìt, bet mantojuma līgums nebūs reǵistrēts zemesgrāmatās, tad šādā gadījumā nevarētu tikt piemērota līgumiskās mantošanas mantojuma pieņemšanas prezumpcija un līgumiskais mantinieks varētu tikt uzskatīts par nezināmu mantinieku, kuram jo īpaši svarīgi būtu ievērot uzaicinājuma termiṇu, lai varētu realizēt savu mantojuma tiesību. 